\title{
Parkin acts as a transcription factor modulating presenilin-1 and presenilin-2 promoter transactivations
}

\author{
Eric Duplan ${ }^{1 *}$, Jean Sévalle ${ }^{1}$, Julien Viotti ${ }^{1}$, Thomas Goiran ${ }^{1}$, Charlotte Bauer ${ }^{1}$, Paul Renbaum², Ephrat Levy-Lahad ${ }^{2}$, \\ Clément A. Gautier ${ }^{3}$, Olga Corti ${ }^{3}$, Nathalie Leroudier ${ }^{1}$, Frédéric Checler ${ }^{1}$, Cristine Alves da Costa ${ }^{1}$
}

From Molecular Neurodegeneration: Basic biology and disease pathways

Cannes, France. 10-12 September 2013

\section{Background}

Parkin is associated to autosomal recessive early-onset Parkinson's disease. Parkin acts as an E3-ubiquitin ligase involved in the proteasome-mediated degradation of various substrates. It has been suggested that pathogenic mutations of parkin, abolishing its ubiquitin-ligase activity, could explain the accumulation of proteins and lead to neuronal death by apoptosis. However, besides this function, additional parkin-dependent cellular pathways exist. We demonstrated that parkin is a direct transcriptional repressor of the tumor suppressor p53 [1]. p53 regulates the expression and functions of presenilin-1 (PS1) and presenilin-2 (PS2), two members of the gamma secretase complex involved in the production of the amyloid $\beta$ peptide $(A \beta)$ and parkin could control the homeostasis of intracellular $A \beta$. These findings prompted us to investigate whether parkin could control presenilins and if so, whether it is via a direct transcriptional control of PS promoters or indirectly, via p53.

\section{Materials and methods}

Experiments were conducted on TSM1 neurons, SHSY5Y human neuroblastoma cells, human embryonic kidney 293 cells, and immortalized mouse embryonic fibroblasts invalidated or not for parkin, presenilin 1 and/or 2, $p 19^{\text {arf }}$ and both $p 19^{\text {arf }} p 53$. We also used primary cultured neurons and brain extract from mouse invalidated or not for parkin.

We did Q-PCR, Western-blot, caspases-3 activity measurement and in vitro gamma secretase assays experiments. We document by chromosome immune-

'IPMC-CNRS UMR 7275, Valbonne, France

Full list of author information is available at the end of the article precipitation, gel shift, gene reporter and mutagenesis experiments parkin direct interaction with presenilins promoters.

\section{Results}

Parkin controls presenilin 1 and 2 expressions, promoter activity, and mRNA levels ex vivo and in mouse brains. This regulation impacts on PS-dependent $\gamma$-secretase activity and presenilin-mediated control of cell death. This control is independent of parkin ubiquitin-ligase activity, does not involve p53 and is not affected by PS1 and PS2 functional interplay. Parkin binds to presenilins promoters via a consensus binding sequence that we identify and validate by functional analysis [2].

\section{Conclusions}

This study is a "framework" for the identification of novel transcriptional targets of parkin and for a better comprehension of parkin's functions.

\section{Acknowledgements}

This work was supported by the 'Fondation pour la Recherche Médicale', the 'Conseil Général des Alpes Maritimes', and the LABEX (excellence laboratory, program investment for the future) DISTALZ.

\section{Authors' details}

${ }^{1}$ IPMC-CNRS UMR 7275, Valbonne, France. ${ }^{2}$ Medical Genetics Institute, Shaare Zedec Medical Center, Hebrew University Medical School, Jerusalem, Israel.

${ }^{3}$ INSERM U679, Hôpital de la Pitié-Salpêtrière, Paris, France.

Published: 4 October 2013

\section{References}

1. da Costa CA, et al: Transcriptional repression of $\mathrm{p} 53$ by parkin and impairment by mutations associated with autosomal recessive juvenile Parkinson's disease. Nat Cell Biol 2009, 11(11):1370-1375. 
2. Duplan $E$, et al: Parkin differently regulates presenilin-1 and presenilin-2 functions by direct control of their promoter transcription. $J \mathrm{Mol}$ Cell Biol 2013, 5(2):132-142.

doi:10.1186/1750-1326-8-S1-P56

Cite this article as: Duplan et al:: Parkin acts as a transcription factor modulating presenilin-1 and presenilin-2 promoter transactivations. Molecular Neurodegeneration 2013 8(Suppl 1):P56.

Submit your next manuscript to BioMed Central and take full advantage of:

- Convenient online submission

- Thorough peer review

- No space constraints or color figure charges

- Immediate publication on acceptance

- Inclusion in PubMed, CAS, Scopus and Google Scholar

- Research which is freely available for redistribution

Submit your manuscript at www.biomedcentral.com/submit
C Biomed Central 